\title{
AESTHETICS IN EARLY CHILDHOOD EDUCATION: THE COMBINATION OF TECHNOLOGY INSTRUMENTS IN CHILDREN'S MUSIC, VISUAL ARTS AND PRETEND PLAY
}

\author{
Chia-Hui Ko and Mei-Ju Chou \\ Department of Early Childhood Education, Taiwan Shoufu University, R.O.C., Taiwan
}

Received 2014-04-13; Revised 2014-04-23; Accepted 2014-04-26

\begin{abstract}
With the importance of aesthetics in current preschool curriculum, children's aesthetics development and deloading learning plays a special attention to the relationship between technology instruments and the three critical early childhood education activities, namely music teaching and learning, visual arts and children's pretend play in early childhood education. A rigorous literature review in Dewey, Steiner and Vygotsky explore the argument that technology instruments play a crucial role in children's daily lives. After carefully elaborating the relevant literature, this study arrives at three major conclusions firstly, indeed technology instruments in music teaching facilitate the quality and efficiency in the young children's learning motivation. Secondly, technology instruments in visual arts facilitate the quality and efficiency in the learning motivation of children and finally, technology instruments of music facilitate children's performance in their pretend play, especially in terms of emotional expression, emotional regulation, emotional utilization and interpersonal relationships. Further, the study reveals that during the application of technology instrument in children's music, visual-arts and pretend play, adults' scaffolding and assistance is no doubt necessary during children's learning and development process.
\end{abstract}

Keywords: Early Childhood Education, Aesthetics, Technology Instruments, Music, Visual Arts, Pretend Play, Young Children

\section{INTRODUCTION}

Normally, early childhood educators are constantly searching for the most effective learning experiences that can help to enhance the quality of education for young children (Lim, 2005) and aesthetic experiences in particular have proven quite successful especially in the teaching of arts and even across disciplines (Harter et al., 2008). Expert analyses have established that aesthetic experiences have the effect of expanding the learning environment thus providing a very important tool that the early childhood education teachers can explore within the integrated curriculum to enrich teaching and learning in the early childhood educations. Dewey (2005) conceptualizes the notion of aesthetic experiences as the moment of quality when individuals realize the aesthetic potential of situations and the ordinary becomes noticeable, thus, they entail all the moments of feeling that provoke deeper inclination that is different from ordinary experiences. Teachers have observed that children become more active and make much more conscious and intentional choices, especially reserved that children become more active and make much more conscious and intentional choices when encouraged to explore and manipulate different material in the classroom and this is because these material intensifies their aesthetic delight. In this respect, in aesthetics early childhood education, the teaching and learning of music in kindergartens, children's visual arts and children's pretend play are certainly the three most significant activities in early childhood education; this is so because such activities suffuse emotional experiences (Lima, 1995) that enrich the learning environments thereby enhancing the children's motivation to learn. A lot of Corresponding Author: Mei-Ju Chou, Department of Early Childhood Education, Taiwan Shoufu University, R.O.C., Taiwan 
research has focused on establishing the systemic relationship between technology instruments and the teaching and learning of music, visual arts and children's performance. Through carefully evaluating the various accounts in relation to these relationships, this study aims to examine the proposal that technology instruments in music in the early childhood education context. Secondly, another noteworthy proposal that this research is keen to investigate is whether technology instruments in visual arts facilitate the quality and efficiency in the learning motivation of children. Additionally, this study will attempt to establish the truth in the proposal that technology instruments facilitate Children's performance in children's pretend play, especially in terms of emotional expression, emotional regulation, emotional utilization and interpersonal relationships. The discussion and conclusion sections of this study will eventually summarize and analyse the findings from the various narratives concerning the relationships between technology instruments and the teaching and learning of music, visual arts and children's performance, in relation to the three proposals established above.

\section{MATERIALS AND METHODS}

\subsection{Aesthetics in Early Childhood Education}

In Aesthetics Early Childhood education, children's music teaching and learning, children's visual arts and children's pretend play are three significant activities in early childhood education; these three activities yield unique experiences that promote learning, especially for the very young children in early childhood educations or early childhood education. There are three major perspectives for the concept of aesthetics in early childhood education pioneered by Dewey, Steiner and Vygotsky and these views provide the theoretical background for the practice of education. According to Dewey (2005), though technique should be secondary to the idea, it should not be neglected, especially because, children often learn from their own images, rather than from the objects. In that case, the early childhood education teachers need to help children to continuously present and develop their own images and attaching their own values to them (Thompson, 2003). Dewey's writings emphasize the importance of aesthetics education because, according to him, taste is determined by the environment-children develop their own standards of taste if they are constantly surrounded by harmonious objects, whereas barren surroundings have the opposite effect of eliminating children's desire for beauty. Dewey redefines the concept of art as a process that involves both the audience and the creator (Gotshalk, 1964) and he sees art as instrumental in enhancing the life experience rather than isolating the aesthetic experience from the lives of individuals. Dewey further posits that the aesthetic experience is a not only a cognitive, but also a psychological, emotional, social and cultural concept, thus, the role of art is to enhance experience-a product of the process of art production and perception, doing and undergoing. Dewey proposes that even though the art object is an integral part of the process of making and perceiving art, the interaction between the object and the audience makes art meaningful as (Shearer, 1935a). Dewey's theory of education proposes that all genuine education comes through experience (Kim, 2009) and each experience must be perceived from each particular student's point of view; in that case, learning, for Dewey, is based on personal experiences (Kazuyo, 2009) and education is a continuous growth in an interaction between objective and internal conditions (Shearer, 1935b). Dewey's makes a strong case in this statement by suggesting that individuals' learn based on their previous experiences, their prior social knowledge and individual awareness of ideal beauty (Harter et al., 2008). For that matter, early childhood education should provide opportunities to link art making to individuals' sense of place and experience to enhance both environmental and artistic perception through the teaching and learning of music, use of visual arts and pretend plays.

Radolf Steiner is yet another remarkable scholar whose ideas have had a magnanimous contribution especially in education theory and practice, for instance, Steiner is best known for his Anthroposophy spiritual movement, which operates on the premises that apart from intellectual dimension, children also need to develop their creative, spiritual and moral dimensions (Gronbach, 2010). According to Steiner, rhythmic physical exercises that are coordinated helps the brain while the background to a good education is the development of the imagination; he likens a child to a sack of finely ground floor that retains any and every impression made on him/her. In that case, between the ages of 0-7 years, every child is a wholly sense organ in all the dimensions and not just in his mind alone. Steiner uses the image of a young girl with an underdeveloped discriminatory consciousness that flows into the world after the world has subsequently flowed into her, thus emphasizing the need to understand the physical environment in the widest possible sense. The physical learning environment in this case represents everything that can be perceived through the senses (such as the teaching and learning of music, use of visual arts and pretend plays) and that can influence the inner powers of 
the child especially because Steiner believed that young children learn through imitation rather than admonition and instruction (Tarr, 2001). In the kindergarten schools context, Steiner was particularly critical of the knowledge and intellectual kindergarten methods because, according to him, an intellectual approach at the early childhood educations would breed weaklings in body and soul who would be unfit in later life.

Vygotsky is yet another outstanding scholar whose philosophical ideas have also had a very profound impact on the education sector; for instance, his theory of education is most renowned for his concept of a zone of proximal development (Kravtsova, 2009), which teachers can use in the guidance of a child's development. Vygotsky's concept of a Zone of Proximal Development (ZPD) is very crucial in the theory and practice of education because it enables a teacher to know what level of activity a child can be able to perform at what age through use of mediator approach (Vygotsky, 1997). Vygotsky conceptualizes the ZPD as the distance between the actual development level as inferred from what tasks the students are able to achieve on their own and the level of potential development that they can achieve under guidance from adults or peers that are more capable. Vygotsky posits that learning takes place at a level just above the level of competence of the learners, thus, it follows undeniably that copying learners will more likely have a greater performance when working with peers that are more competent. Additionally, another remarkable feature of Vygotsky's theory of education is the significant role of play in the education of children because according to his perspective, teachers are supposed to provide children, especially the young ones, with opportunities to play. Vygotsky conceptualizes that through play and imagination, children are able to grow and develop their conceptual abilities; play leads to development because, through the imitation of elders in culturally patterned activities, children afford opportunities for intellectual development. Usually, the plays and games are recollections and re-enactments of real situations and later, through the dynamics of their imagination and recognition of implicit rules that govern the activities the children have reproduced in those games, children eventually achieve what can be termed as an elementary mastery of abstract thought.

\subsection{Technology Instruments, Aesthetics and Early Childhood Education}

Developmental concerns have traditionally challenged the use of technology in early childhood settings due to moral panics (Yelland, 2006), but technology has resulted to the unprecedented increase in critical areas (Hansen, 2008) and today, researchers have subsequently revised their query from whether or not technology can be applied to how technology can be applied to enhance early childhood literacy instruction. There are many technology instruments that can be applied in literacy instruction in early childhood education; for instance, research has shown that many children love working with computers and actually socialize, talk, plan and even collaborate more around computers than they do around other traditional forms of play material. Computer-based technology is one of the effective early childhood literacy instructions that have resulted to remarkable outcomes especially in terms of increased comprehension, vocabulary, fluency and achievement. In early childhood education, technology instruments can be located in many areas of the classroom situation (Ntuli and Kyei-Blankson, 2012), with many teachers reporting incorporation of technology instruments in instruction. Teachers and schools play a very significant role in the integration of technology in the early childhood education (Wang and Hoot, 2006), thus, they must play a proactive role of ensuring that children are exposed to various technology instruments to enhance their experiences. Technology instruments in children's music teaching and learning, children's visual arts and in children's pretend play influences both the quality and efficiency of children in children's learning motivation.

\subsection{Technology Instruments in Children's Music Teaching and Learning}

After elaborating the literature and argument, the following proposition emerges, technology instruments in music teaching facilitate the quality and efficiency in children's learning motivation. Music educators are currently exploring technology as a tool for the teaching and learning of music by children in the early childhood education (Dillon, 2003) and in this case, computers and the internet offer a myriad of multimedia resources as interesting platforms for young children to experience music. There is an increasing realization of newly conceived technologies in music and/or technology oriented musical instruments and toys that allow learning activities in music to occur in early childhood education. Technology instruments in early childhood education allow aural learning to be supported by both visual and psychomotor domains of the children and music activities include social interaction (Fred, 2006). The successful inclusion of 
technology in music for young children in early childhood education will vary depending on the physical, mental and social readiness of each child, thus, the learning providers must assess the readiness of every child to use particular technologies in music before adopting them for learning in the classroom. The various technology instruments that can be explored in the teaching and learning of music in early childhood education include musical toys, keyboard instrument toys and percussion and guitar instrument toys, in addition to sound and music computer software. Musical toys are perfect tools for participation and learning especially because many of them are userfriendly and even children with little or hardly any experience can set them up to provide strong opportunities for sound exploration and performance. Keyboard instrument toys on the other hand will have different features depending on their prices-some will play background accompaniment for singing, others have microphone reproduction capabilities that allow children to hear themselves as they sing, in addition to having harmonics and/or rhythmic backgrounds. Percussion and guitar instrument toys also provide opportunities for young children to experience and create with rhythm and harmony, for instance, drum pads are cheap toys that allow considerable experimentation with rhythm and percussion timbres. Similarly, there are electric guitars, banjos and electronic drumsticks suitable for young children, which produce rhythmic backgrounds, chord harmony, in addition to opportunities for children to sing, create and record themselves while at it. There is also a noteworthy increase in music software designed specifically for the young children in early childhood education; besides providing opportunities for the experiencing the music elements, most recent titles have incorporated parent interaction and guidance. Having located technology instruments in the teaching and learning of music in early childhood education, there is indeed a substantial consistency in various sources in support of the first proposal. It is clear that technology instruments in music teaching and learning facilitate the quality and efficiency in children's learning motivation because they provide interactive environments that stimulate young children's music skills (Panagiotakou and Pange, 2010). In this respect, early childhood educators must provide opportunities that familiarize themselves with technology instruments at an early age and further opportunities for improving musical involvement and developing expertise while working with technology that features manipulation of musical elements. Thus:

\section{Proposition one: Technology Instruments in Music Teaching Facilitates the Quality and Efficiency in Children's' Learning Motivation}

\subsection{Technology Instruments in Children's Visual Arts}

After elaborating the literature and argument, the second proposition emerges that technology instruments in visual arts facilitate the quality and efficiency in the learning motivation of young children. There is sufficient evidence now than ever before as to how children learn and the kinds of activities and things that act as efficient tools for learning in early childhood education; audiovisual materials such as pictures, charts, maps, slides, film-strips and recordings make a significant contribution to learning when used appropriately, thereby reinforcing oral instruction, exercises and textbooks. In their formative years of learning, children are highly impressionable, relying on their sensory perceptions including hearing, seeing, touching, smelling and manipulating things in the environment to establish a sense of place and environmental perception (Andri et al., 2004). In this regard, the sensory perceptions of a child reinforce and enrich the his or her perception because they offer a variety of experiences which stimulate the child's senses thereby promoting self-activity in them. Audio-visuals provide the child with concrete images and rich perceptual experiences forming the basis for learning in early childhood education instead of presenting children with facts to be memorized (Bruce, 1995). Conversely, early childhood education at this level should focus majorly on arising the curiosity of the child; stimulating their senses, motivating inquiry and helping them achieve a profound perceptual growth. The teacher's role is to plan and organize appropriate learning experiences with the management of a variety of learning and teaching materials to create the most stimulating environments for learning (Bae, 2004). Additionally, the teacher also responsible for the important task of conveying ideas to children as skilfully as possible (Wallerstedt and Pramling, 2012), using various visual arts in different forms because the child has a short concentration span and they easily get bored with words but would enjoy looking at pictures. Consistent with research findings, 
about $80 \%$ of learning occurs through the senses, thus, a planned use of visual arts help to enhance learning in early childhood education and this becomes the basis for the principle of visual arts to education. Visual arts range from the traditional blackboard to the much modern technology instruments including, but not limited to the tape recorder, the film projector, in addition to radio and television, which normally have a compelling force that focuses the attention of child, challenging imagination. However, the major challenge of applying recent technologies in the early childhood education is the cost implications because most of them are so expensive, especially the films, film-strips, slides, in addition to the transparencies which entail the use of expensive projection technologies such as film projectors, film-strip projectors, slide projectors and overhead projectors. Nevertheless, it is undisputable that indeed incorporation of technology instruments in visual arts facilitates the quality and efficiency in the learning motivation of children because they provide opportunities for young children to experience learning through their senses, reinforcing oral instruction, exercises and textbooks. In this respect, early childhood educators should plan to incorporate technology instruments in visual arts to ensure the child is in settings that support and provide quality experiences (Slutsky and Pistorova, 2011), to reinforce and enrich his/her perceptions. It is therefore:

Proposition two: Technology Instruments in Visual Arts Facilitates the Quality and Efficiency in Children's' Learning Motivation

\subsection{Technology Instruments in Children's Pretend Play Performance}

After elaborating the literature and argument, the third proposition emerges that technology instruments facilitate children's pretend play performance (emotional expression, emotional regulation, emotional utilization and interpersonal relationship) in children's pretend play activities and pretend play (Ulaş, 2008). Pretend play is very a very essential part of a child's life; in that case, early childhood education must provide the child with opportunities to develop their imagination by equipping them with spaces, scenarios, props and the support they need to explore their real or imagined worlds. Apart from promoting the child's intellectual development, pretend plays also enhance the child's social skills and creativity by giving them an opportunity to re-enact events that they have observed and/or experienced in life. Setting up the pretend play is a crucial part of the process as it must reflect the familiar environments that kids are used to in their daily lives and it should include all the relevant props in particular case scenarios for children to connect and focus on the intended themes. In the fast changing technology driven world, where technology results to rapid changes in society (Siu and Lam, 2005) and educators should explore the benefits of technology instruments inclusion in children's pretend plays and pretend play performance in early childhood education. In this age of information communication technologies, children often interact with many technology instruments in various settings and such interaction enhances the child's knowledge of their surroundings (Wallerstedt and Pramling, 2012). As stated in the third proposal, technology instruments indeed facilitate children's performance in children's pretend play and pretend play performance because they lead to concrete emotional expression, emotional regulation (App and MacDonald, 2012), emotional utilization (Andri et al., 2004) and interpersonal relationships (Wang and Hoot, 2006). In that case, children are provided with the opportunity to explore various technologies in the pretend plays, thereby being able to express themselves clearly, regulate their emotions and to socialize through such technologies. Thus, technology instruments of music facilitate Children's performance arts toward the enhancement in learning motivation and recreation for the young children:

\begin{abstract}
Proposition three: Technology Instruments of Music Facilitates Children's Pretend Play Performance, especially in terms of emotional expression, emotional regulation, emotional utilization and interpersonal relationships
\end{abstract}

\section{RESULTS AND DISCUSSION}

Aesthetics is a very crucial concept in early childhood education these days with the current knowledge of the significant role it plays in the instruction of young children. The concept is concerned with the knowledge based on sensory experiences or perceptions, because children's sensory skills enable them to respond to the qualities of things in their immediate surroundings. Additionally, aesthetic development in children requires them to be aware of the things they observe such as colour, figure, form texture, size, balance, volume, in addition to movement, among other things. The theoretic background of aesthetic early 
childhood education has greatly been influenced by Dewey, Steiner and Vygotsky; for instance, Dewey's theory of education proposes that all genuine education comes through experience and each experience must be perceived from each particular student's point of view. Apart from intellectual dimension, Steiner's theory of education presupposes that children also need to develop their creative, spiritual and moral dimensions, while Vygotsky's theory of education emphasizes the role of play in the development of children's conceptual abilities. With the myriad technological advancements influencing society's progress and development today, increasing discourses have centred on the argument for incorporating technology instruments in children's music teaching and learning, children's visual aid and children's pretend play in early childhood education.

\section{CONCLUSION}

After a rigorous exploration of resources and the argument, three major proposals have emerged; the first proposal is that technology instruments in music teaching facilitate children's learning. It is indubitable that technology instruments such as musical toys, keyboard instrument toys and percussion and guitar instrument toys, in addition to sound and music computer software enhance learning experiences. The second proposal suggests that technology instruments in visual arts facilitate children's learning; visual arts promote learning in early childhood education because they enable the child to form mental images of things in the environment thus enriching their perceptions. In that case, visual arts provide the child with an opportunity to explore his/her sensory perceptions including hearing, seeing, touching, smelling and manipulating things in the environment to establish universal truths about them. The sensory perceptions of a child reinforce and enrich his or her perception because they offer a variety of experiences, which stimulate the child's senses thereby promoting selfactivity, reinforcing oral instruction, exercises and textbooks. The third and final proposal is that technology instruments of music facilitate children's performance in pretend play thus leading to more fruitful social interactions, increased imagination, learning motivation and recreation creativity for young children. Given the consistency in findings, educators in early childhood education should notice that adults scaffolding in children's learning in aesthetics early childhood education is necessary.

\section{REFERENCES}

Andri, S., E. Trimis and Z. Aravella, 2004. Exploring the links between visual arts and environmental education: Experiences of teachers participating in an in-service training programme. Int. J. Art Design Educ., 23: 246-255. DOI: $10.1111 /$ j.14768070.2004.00404.x

App, L. and M. MacDonald, 2012. Classroom aesthetics in early childhood education. J. Educ. Learn., 1: 4959. DOI: 10.5539/jet.v1n1p49

Bae, J., 2004. The arts in early childhood-learning to teach visual arts in an early childhood classroom: The teacher's role as a guide. Early Childhood Educ. J., 31: 247-254. DOI: 10.1023/B:ECEJ.0000024116.74292.56

Bruce, P.U., 1995. Uncommon schooling: A historical look at Rudolf Steiner, anthroposophy and waldorf education. Curriculum Inquiry, 25: 381-406. DOI: 10.2307.2F1180016

Dewey, J., 2005. Art as Experience. 1st Edn., Penguin, New York, ISBN-10: 0399531971, pp: 371.

Dillon, T., 2003. Collaborating and creating on music technologies. Int. J. Educ. Res., 39: 893-897. DOI: 10.1016/J.IJER.2004.11.011

Fred, K., 2006. Inclusion of technology resources in early childhood music education. General Music Today, 20: 15-28. DOI: $10.1177 / 10483713060200010105$

Gotshalk, W., 1964. On dewey's aesthetics. J. Aesthet. Art Criticism, 2: 131-138. DOI: $10.2307 / 428146$

Gronbach, S., 2010. Anthroposophy from the inside: What people have wanted to know about anthroposophy and not found in Wikipedia. Integral Leadership Rev., 10: 1-3.

Hansen, C.C., 2008. Observing technology enhanced literacy learning. Contemporary Iss. Technol. Teacher Educ., 8: 108-121.

Harter, L.M., M. Leeman, S. Norander, S.L. Young and W.K. Rawlins, 2008. The intermingling of aesthetic sensibilities and instrumental rationalities-in a collaborative arts studio. Manage. Commun. Q., 21: 423-453. DOI: 10.1177/0893318907313711

Kazuyo, N., 2009. The significance of dewey's aesthetics in art education in the age of globalization. Educ. Theory., 59: 427-440. DOI: $10.1111 /$ j.1741-5446.2009.00329.x

Kim, J., 2009. Dewey's aesthetics and today's moral education. Educ. Culture, 25: 62-75. DOI: 10.1353/eac. 0.0040 
Kravtsova, E.E., 2009. The cultural-historical foundations of the zone of proximal development. J. Russian East Eur. Psychol., 47: 9-24. DOI: 10.2753/RPO1061-0405470601

Lim, B., 2005. Aesthetic experience in a dynamic cycle: Implications for early childhood teachers and teacher educators. J. Early Childhood Teacher Educ. 25: 367-373. DOI: 10.1080/1090102050250411

Lima, M.G., 1995. From aesthetics to psychology: Notes on vygotsky's psychology of art. Anthropol. Educ. Q., $\quad 26: \quad 410-424$. DOI: $10.1525 /$ aeq. 1995.26.4.05x1061u

Ntuli, E. and L. Kyei-Blankson, 2012. Teacher assessment of young children learning with technology in early childhood education. Int. J. Inform. Commun. Technol. Educ., 8: 1-10. DOI: 10.4018/jicte.2012100101

Panagiotakou, C. and J. Pange, 2010. The use of ICT in preschool music education. Social Behavioral Sci., 2: 3055-3059. DOI: 10.1016/j.sbspro.2010.03.464

Shearer, E.A., 1935a. Dewey's esthetic theory I. J. Philosophy, 32: 617-627. DOI: 10.2307/2016245

Shearer, E.A., 1935b. Dewey's esthetic theory II. J. Philosophy, 32: 650-664. DOI: 10.2307/2016825

Siu, K.W.M. and M.S. Lam, 2005. Early childhood technology education: A sociocultural perspective. Early Childhood Educ. J., 32: 353-358. DOI: 10.1007/s10643-005-0003-9

Slutsky, R. and S. Pistorova, 2011. Making high-quality early childhood settings visible: Life at little garden preschool. Scholarly Partnerships Educ., 5: 45-56.
Tarr, P., 2001. Aesthetic codes in early childhood classrooms: What art educators can learn from Reggio Emilia. Art Educ., 54: 33-39. DOI: $10.2307 / 3193922$

Thompson, C.M., 2003. Kinderculture in the art classroom: Early childhood art and the mediation of culture. Studies Art Educ., 44: 135-146.

Ulaş, A.H., 2008. Effects of Creative, Educational Drama Activities on Developing Oral Skills in Primary School Children. Am. J. Applied Sci., 5: 876-880. DOI: 10.3844/ajassp.2008.876.880

Vygotsky, L.S., 1997. The Collected Works of L.S. Vygotsky: The History of the Development of Higher Mental Functions. 1st Edn., Springer, New York.

Wallerstedt, C. and N. Pramling, 2012. Conceptualising early childhood arts education: The cultivation of synesthetic transduction skills. Int. J. Early Childhood, 44: 127-139. DOI: 10.1007/s 13158-012-0057-y

Wang, X. and J.L. Hoot, 2006. Information and communication technology in early childhood education. Early Educ. Dev., 17: 317-322. DOI: 10.1207/s15566935eed1703_1

Yelland, N., 2006. New technologies and young children: Technology in early childhood education. Teacher Learn. Netw., 13: 10-13. 